\title{
The primordial chondritic nature and large-scale heterogeneities in the mantle: evidence from high and low partition coefficient elements in oceanic basalts $\dagger$
}

\author{
By H. Bougault, $†$ J. L. Joron§ and M. Treuil $\S$ \\ $\uparrow$ Centre Océanologique de Bretagne, CNEXO, B.P. 337, 29273 Brest cedex, France \\ $\S$ Institut de Physique du Globe, 4 place Jussieu, 75230 Paris cedex 05, \\ and Laboratoire Pierre Sue, Centre d'Études Nucléaires de Saclay, B.P. no. 2, \\ 91190 Gif-sur-Yvette, France
}

- Large-scale heterogeneities in the mantle are investigated through trace elements measured in oceanic basalts from different locations in the Atlantic and Pacific oceans. The study relies upon the physico-chemical properties of the elements and their classification according to their partition coefficients. High partition coefficient elements (Co, Ni, $\mathrm{Cr}$ ) have concentrations in peridotite that are not sensitive to solidliquid equilibrium (partial melting); the mantle should therefore be homogeneous with respect to these elements. The ratios of elements that have equal or very similar low partition coefficients ( $\mathrm{Y} / \mathrm{Tb}, \mathrm{Zr} / \mathrm{Hf}$ and $\mathrm{Nb} / \mathrm{Ta}$ ) are constant in all samples studied, despite their large concentration range. These ratios are equal to chondritic ratios and favour a chondritic nature for the primordial mantle. The La/Ta ratio shows two values, either 9 or 18 , which are closely related to topography ( 9 for topographic highs).

When the difference between partition coefficients of two hygromagmaphilic elements increases, the local variations observed for their ratio can be interpreted either as local heterogeneities of mantle sources or as the effect of magmatic processes (e.g. partial melting).-

\section{INTRODUGTION}

The notion of homogeneity or heterogeneity of the mantle has to be defined in terms of scale and time. With respect to time, unless some relation can be shown between trace element behaviour and the age of the oceanic crust, heterogeneity with time in the mantle can only be investigated through radioactive elements and the chemical behaviour of parent-daughter isotopes. In terms of scale, if we look at peridotite nodules, heterogeneity is evident on the scale of a hand specimen (see, for example, Nixon \& Boyd 1973; Boullier \& Nicolas 1973; Cox et al. I973; Gurney \& Harte, this symposium). The information obtained from hand specimen peridotites can be interpreted as mineralogical equilibrium against temperature and pressure and also as the result of processes occurring within the mantle or in the course of their uplift to the surface.

The study of basalts erupted at mid-oceanic ridges can be considered as a window into the mantle in that it enables us to assess the homogeneity or heterogeneity of the mantle on different scales, provided that we know how the parameters measured from basalts are genetically related to their mantle source. First of all we have to note that a process, such as partly melting a portion of the mantle, necessarily causes heterogeneities since this process occurs to different extents in space and time at mid-oceanic ridges. Partial melting is an excellent example of the

† Contribution no. 631 du Centre Océanologique de Bretagne. 
ambiguity that can arise when considering the nature of the mantle and the extent of a process since the process itself necessarily acts on the composition of the mantle source involved. To define the concept of homogeneity or heterogeneity in the mantle that we have in mind for this study, we stress that this concept is dependent upon the trace elements considered, and that we are mainly considering possible heterogeneities on a large scale, trying to avoid as far as we can the fractionating effects of partial melting processes associated with basalt generation.

\section{LOCATION OF STUDIED SAMPLES}

In the Atlantic ocean, the locations of samples that we have been studying are as follows: $63^{\circ} \mathrm{N}$ : three sites, $407,408,409$, were drilled during Leg 49 of the D/V Glomar Challenger (D.S.D.P.-Irod Program) along a track perpendicular to the Reykjanes Ridge (Luyendyk et al. 1979).

$45^{\circ} \mathrm{N}$ : one drilled site, 410 (Luyendyk et al. 1979).

$36^{\circ} \mathrm{N}$ : the Famous operation provided an intensive sampling both by dredging and by submersible in the Rift Valley and adjacent fracture zones (Bougault \& Hékinian 1974; Arcyana 1977). At the same latitude, four sites $(332,333,334,335)$ were drilled during Leg 37 by the $\mathrm{D} / \mathrm{V}$ Glomar Challenger along a track perpendicular to the ridge and sampled crust up to $16 \mathrm{Ma}\left(16 \times 10^{6}\right.$ years) old (Aumento et al. 1977). In addition, three other sites, 411, 412, 413, were drilled during Leg 49 close to the FAmous area itself (Luyendyk et al. 1979).

$22^{\circ} \mathrm{N}$ : two sites, 395 and 396 , almost symmetric to the ridge, and about 7 and $10 \mathrm{Ma}$ old on the western and eastern part of the ridge respectively, were drilled during Legs 45 and 46 of the Glomar Challenger (Melson et al. 1978; Dmitriev et al. 1978).

$25^{\circ} \mathrm{N}$ : the 'megaleg' (Legs 51, 52 and 53) drilled Sites 417 and 418, in $110 \mathrm{Ma}$ old crust located along the same 'flow line' as Sites 395 and 396 (Donnelly et al. 1979).

In the Pacific ocean, during Leg 54, the Glomar Challenger drilled several sites: the western flank of the East Pactific Rise at $9^{\circ} \mathrm{N}$, Sites 420, 421 (ca. 3.5 Ma), 423 (ca. 1.2 Ma), 422, 428 $(c a .2 \mathrm{Ma})$ and $429(c a .4 .5 \mathrm{Ma})$; the Galapagos spreading centre at $0^{\circ} \mathrm{N} 86^{\prime} \mathrm{W}$, Site 424 $(\mathrm{A}, \mathrm{B}, \mathrm{C})$ and Site 425 (60 $\mathrm{km}$ from the axis); and the Siqueiros Fracture zone, Site 427 $\left(8^{\circ} \mathrm{N}, 5 \mathrm{Ma}\right)$ (Hékinian et al. r980).

In addition to these data on basaltic samples, results obtained on different peridotites from the Alps and Pyrénées and from xenoliths in kimberlites pipes (Bougault \& Allègre 1979) will be used in connection with basalt data, mainly for information that can be deduced from high partition coefficient elements.

\section{High partition coefFigient elements}

The partition coefficient is defined as the ratio of the concentration of the considered element in a mineral to its concentration in the liquid with which it is in equilibrium. The expression 'high partition coefficient element' is used to describe those elements whose bulk partition coefficient is high with respect to such equilibrium between liquid and assemblage of minerals. Figure 1 gives the partition coefficients of the first transition metals for different minerals against the atomic number, from titanium to zinc. These partition coefficients were obtained from concentration measurements in minerals separated either from peridotites (spinel, orthopyroxene, clinopyroxene, olivine) or from oceanic basalts (olivine, plagioclase, clinopyroxene). 
$\mathrm{Ni}$ partition coefficients are dependent on the $\mathrm{Mg}$ content of the liquid (Hart et al. 1976). The $\mathrm{Ni}$ partition coefficient for olivine was obtained after separation of olivine and glass from a basaltic sample (Bougault \& Hékinian 1974). The olivine phenocrysts contain glass inclusions whose major element compositions have been measured by an electron microprobe. Major element concentrations of both glassy matrix and inclusions are given in table 1 . The similarity of compositions allows us to consider olivine and liquid (glass) in equilibrium; in consequence the partition coefficients found for olivine can be used for calculations relative to tholeiitic liquid-olivine equilibrium. The partition coefficient data presented in figure 1 are in reasonably

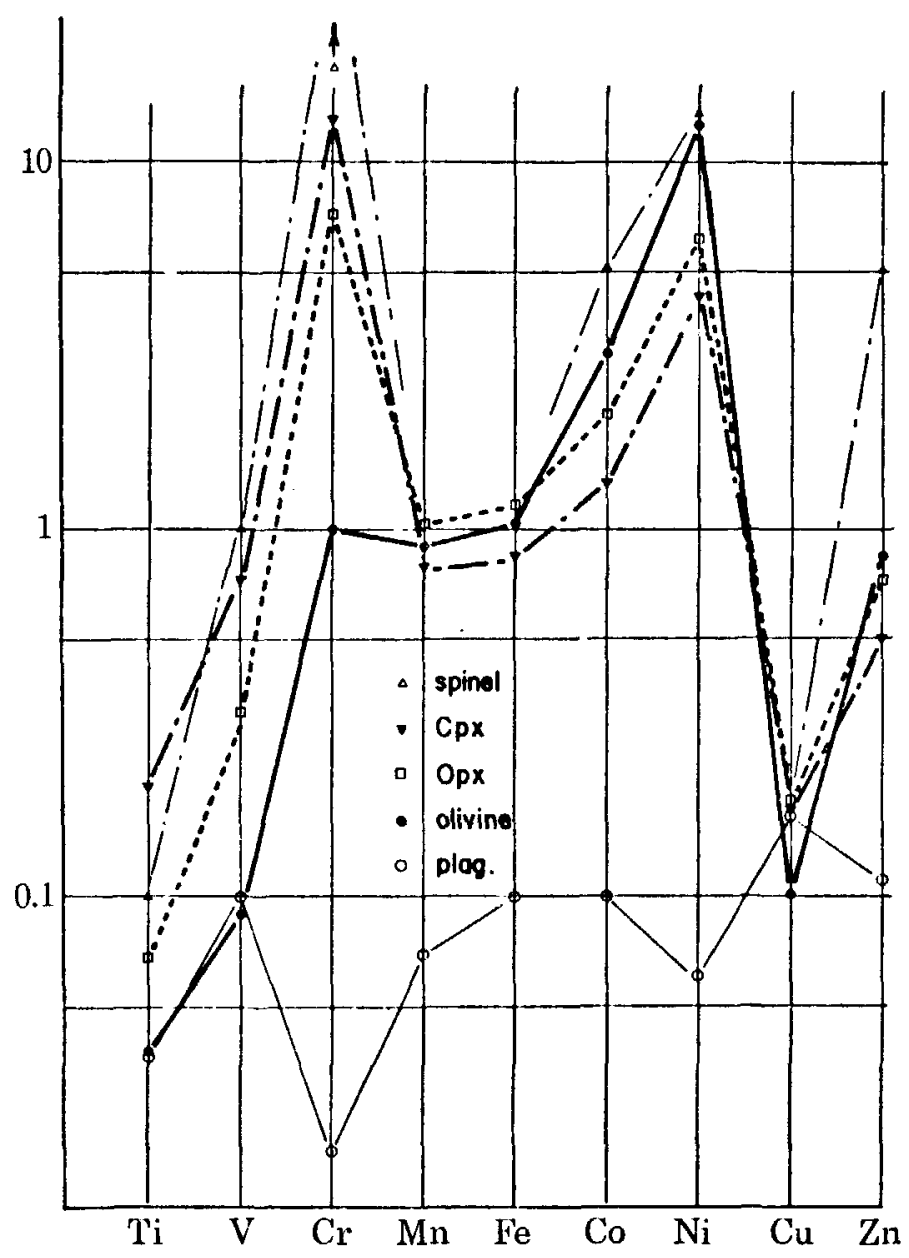

FIGURE 1. First transition series: partition coefficients.

TABle 1. Concentrations of Major elements of glassy matrix and glass INCLUSIONS IN OLIVINE FROM WHICH PARTITION GOEFFICIENTS IN OLIVINE WERE DEDUGED

\begin{tabular}{|c|c|c|c|}
\hline & $\begin{array}{c}\text { olivine } \\
\left(\mathrm{Fo}_{88.6}\right)\end{array}$ & $\begin{array}{c}\text { glass } \\
\text { inclusion }\end{array}$ & glass matrix \\
\hline $\mathrm{SiO}_{2}$ & 40.5 & 49.5 & 49.0 \\
\hline $\mathrm{TiO}_{2}$ & 0 & 0.7 & 0.8 \\
\hline $\mathrm{Al}_{2} \mathrm{O}_{3}$ & 0.1 & 15.8 & 15.8 \\
\hline $\mathrm{FeO}$ & 10.3 & 8.6 & 8.7 \\
\hline $\mathrm{MnO}$ & 0.2 & 0.2 & 0.2 \\
\hline $\mathrm{MgO}$ & 47.8 & 8.8 & 9.3 \\
\hline $\mathrm{CaO}$ & 0.35 & 13.2 & 12.8 \\
\hline $\mathrm{Na}_{2} \mathrm{O}$ & 0 & 1.5 & 1.8 \\
\hline \multirow[t]{2}{*}{$\mathrm{K}_{2} \mathrm{O}$} & 0 & 0.2 & 0.2 \\
\hline & 99.25 & 98.5 & 98.60 \\
\hline
\end{tabular}


good agreement with other published data (Hakli \& Wright 1967; Hakli 1968; Dale \& Henderson 1972).

The general shape of partition coefficients of ferromagnesian minerals against atomic number (figure 1) agrees with the crystal field stabilization in octahedral structures (Burns 1970; Curtis 1964); three elements in the series, $\mathrm{Cr}, \mathrm{Ni}$ and $\mathrm{Co}$, have high partition coefficients, the highest values being found for $\mathrm{Cr}$ and $\mathrm{Ni}$ (corresponding to the highest stabilization energies in the series). Figure 1 also shows that $\mathrm{Ti}$ and $\mathrm{V}$ have partition coefficients less than one, confirming that these two elements behave like 'incompatible' or 'hygromagmaphile' elements.

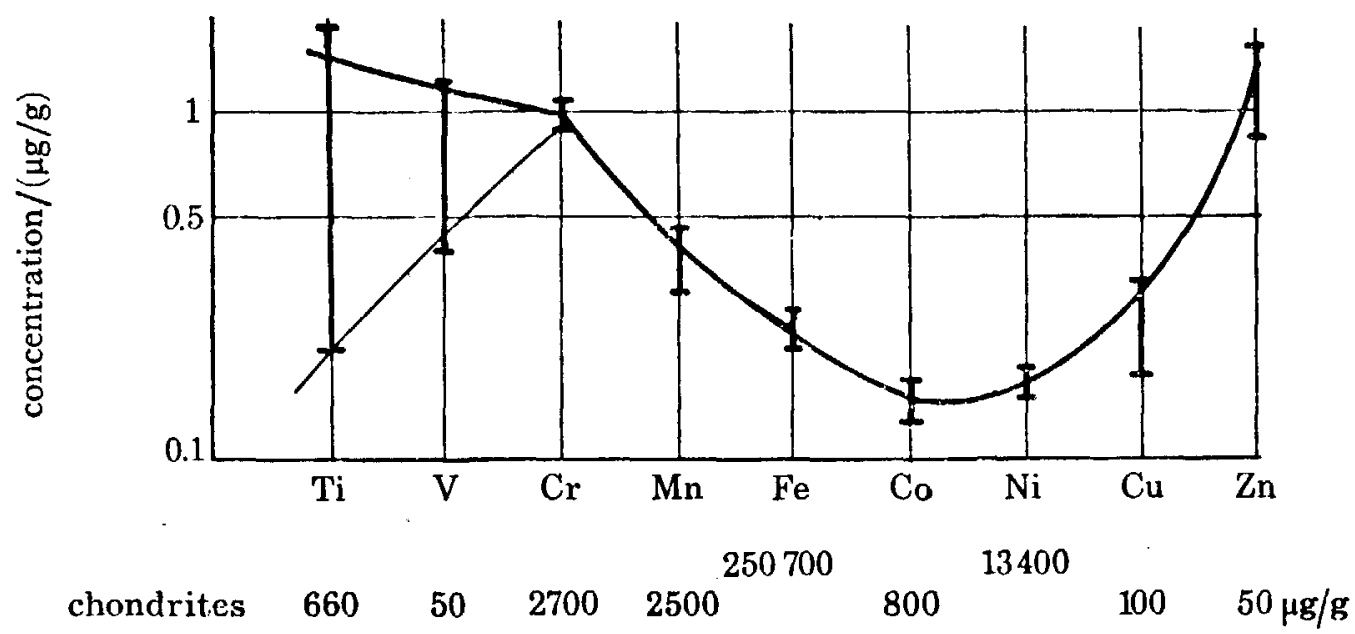

Figure 2. First transition series: concentrations (normalized to chondrites) against atomic numbcr.

$\mathrm{Co}, \mathrm{Ni}$ and $\mathrm{Cr}$ concentrations, both in the residue and in the liquid, have been computed in terms of the extent of partial melting by using the partition coefficients of figure 1 . These calculations were made for different compositions of peridotites and by using different models (i.e. phase proportions and melting modes) for partial melting (Bougault 1977). The results are as follows: for the solid, the concentration ratio of the residue to the initial solid remains in the range 1.0-1.2 for $\mathrm{Co}, \mathrm{Ni}$ and $\mathrm{Cr}$ between 0 and $c a .30 \%$ of melting independently of the model and the composition of the peridotite; the ratio of the concentration in the liquid to that in the initial solid is almost constant with a value of about 0.11 for $\mathrm{Ni}$ and about 0.41 for Co. For Cr, the result depends on the chosen model, the proportion of spinel in the initial solid, and the proportion of spinel melted.

Figure 2 represents the transition element concentrations in peridotites normalized to chondritic meteorites, as proposed by Allègre et al. (1968) and used by Bougault \& Hékinian (1974) and Langmuir et al. (1977). This diagram is used here to show the range of variation of the elements in connection with the theory developed above. The possible implications for Earth differentiation will be discussed later (Bougault \& Allègre 1979). Ti and V, whose partition coefficients are less than unity, are sensitive to partial melting (or liquid-solid equilibrium). For a large variation of $\mathrm{Ti}$ and $\mathrm{V}$ in the studied samples ( $\mathrm{Ti}$ variation being larger than $\mathrm{V}$ variation, as predicted by the measured partition coefficients), $\mathrm{Cr}, \mathrm{Ni}$ and $\mathrm{Co}$ show a narrow range of variation. Since, for these elements, the ratio of concentration in the residue to concentration in the initial solid does not vary significantly with melting, the concentrations of $\mathrm{Cr}, \mathrm{Ni}$ and $\mathrm{Co}$ should be homogeneous in the mantle. Similar results have been shown by Sato (1977) for $\mathrm{Ni}$. 
$\mathrm{Cr}$ and $\mathrm{Ni}$ concentrations have, however, a large range of variation in basaltic liquids due to crystallization processes. Co varies between 40 and $50 \mu \mathrm{g} / \mathrm{g}$. Because of crystallization effects, if some relation exists between $\mathrm{Ni}, \mathrm{Cr}$ and Co concentrations in the mantle and in basaltic liquids, it is necessary to consider liquids that can be regarded as 'primitive' or undifferentiated through fractional crystallization. Such liquids have been found in the Famous area (table 2) with $\mathrm{MgO}$ values between 10.6 and $11.5 \%$ and a $\mathrm{Mg} /(\mathrm{Mg}+\mathrm{Fe})$ atomic ratio around 0.7 .

Table 2. Congentrations of some elements in 'PRimitive' liquids REGOVERED IN THE FAMOUS AREA

\begin{tabular}{|c|c|c|c|c|c|c|c|}
\hline & $\begin{array}{r}\mathrm{MgO} \\
(\%)\end{array}$ & $\frac{\mathrm{Mg}^{2+}}{\mathrm{Mg}^{2+}+\mathrm{Fe}^{2+}}$ & $\frac{\mathrm{Ni}}{\mu \mathrm{g} / \mathrm{g}}$ & $\frac{\mathrm{Ti}}{\mu \mathrm{g} / \mathrm{g}}$ & $\frac{\mathrm{Tb}}{\mu \mathrm{g} / \mathrm{g}}$ & $\frac{\mathrm{La}}{\mu \mathrm{g} / \mathrm{g}}$ & $\frac{\mathrm{Ta}}{\mu \mathrm{g} / \mathrm{g}}$ \\
\hline $\begin{array}{c}411-1-1 \\
78-82\end{array}$ & 11.5 & 0.7 & 265 & 4184 & 0.44 & 2.4 & 0.23 \\
\hline CYP $31-35$ & 10.6 & 0.72 & 253 & 5100 & 0.42 & 5.4 & 0.52 \\
\hline $\begin{array}{c}4133-1 \\
44-48\end{array}$ & 10.6 & 0.68 & 240 & 8573 & 0.58 & 14.6 & 1.61 \\
\hline
\end{tabular}

The different values of 'hygromagmaphile' elements or ratios of these elements clearly indicate that these liquids were produced either by different partial melting processes from the same source or from different sources. Nevertheless the Ni concentrations remain approximately constant, confirming the theoretical results, i.e. the non-dependence of $\mathrm{Ni}$ concentration in the 'primitive' liquids, whatever the degree of partial melting or the source material. In addition the $\mathrm{Ni}$ and Co concentrations (ca. 250 and $c a .50 \mu \mathrm{g} / \mathrm{g}$ ) fit with the values obtained from calculations with the use of measured partition coefficients. For $\mathrm{Ni}$ the ratio $\left(C_{\mathrm{l}} / C_{\mathrm{i}}\right) C_{\mathrm{p}}$, where $C_{1}$ is the concentration in the liquid, $C_{\mathrm{i}}$ the concentration in the initial solid and $C_{\mathrm{p}}$ the concentration in the initial solid (from peridotites), is $0.11 \times 2200 \mu \mathrm{g} / \mathrm{g}=242 \mu \mathrm{g} / \mathrm{g}$; for Co this is $0.41 \times 125 \mu \mathrm{g} / \mathrm{g}=51 \mu \mathrm{g} / \mathrm{g}$.

For high partition coefficient elements, provided that a phase (or several phases) in the solid acts as a buffer with respect to melting processes or solid-liquid equilibrium, their concentrations in both the solid and the liquid are not dependent upon the extent of melting. This feature makes these elements unsuitable for observations of possible heterogeneities in the mantle.

From the results obtained both from peridotites and primitive liquids it can be concluded that the mantle is homogeneous with respect to $\mathrm{Ni}$, Co and probably $\mathrm{Cr}$.

\section{4. 'LOW PARTition', 'INCOMPATIBLE' OR 'HYGROMAgMaphile' ELEMENTS}

A 'low partition coefficient' element can be defined in a similar way as for 'high partition coefficient' elements: it is an element whose bulk solid-liquid partition coefficient is lower than one. This definition covers both the notions of 'incompatible' and 'hygromagmaphilic'. 'Incompatible' relates to the difficulty that an ion has in entering into a crystal structure because of, for instance, its ionic radius. 'Hygromagmaphilic' is related to the ability of an ion to form complexes in or have an affinity for the liquid (Treuil 1973; Treuil \& Joron 1975).

In contrast to 'high partition coefficient' elements, the 'hygromagmaphilic' element concentrations in the liquid vary extensively as a function of the degrees of partial melting as well as a response to crystallization processes. Rather than considering absolute values, we 
consider ratios of two of these elements. Such a ratio does not vary a great deal in the course of crystallization processes, but whatever model is chosen, it may vary in both the solid (residuc of melting) and the liquid during partial melting. Whatever the chosen partial melting model, the fractionation of two of these elements is less when thesc elements have lower partition coefficients and lower differences between their partition coefficients. Thus, to demonstrate possible long-lived mantle heterogeneities through variation in the magmaphile elements, it is necessary to disregard the local effects that can be produced by partial melting and in consequence to consider a pair of elements whose partition coefficients are as close to each other and as low as possible.

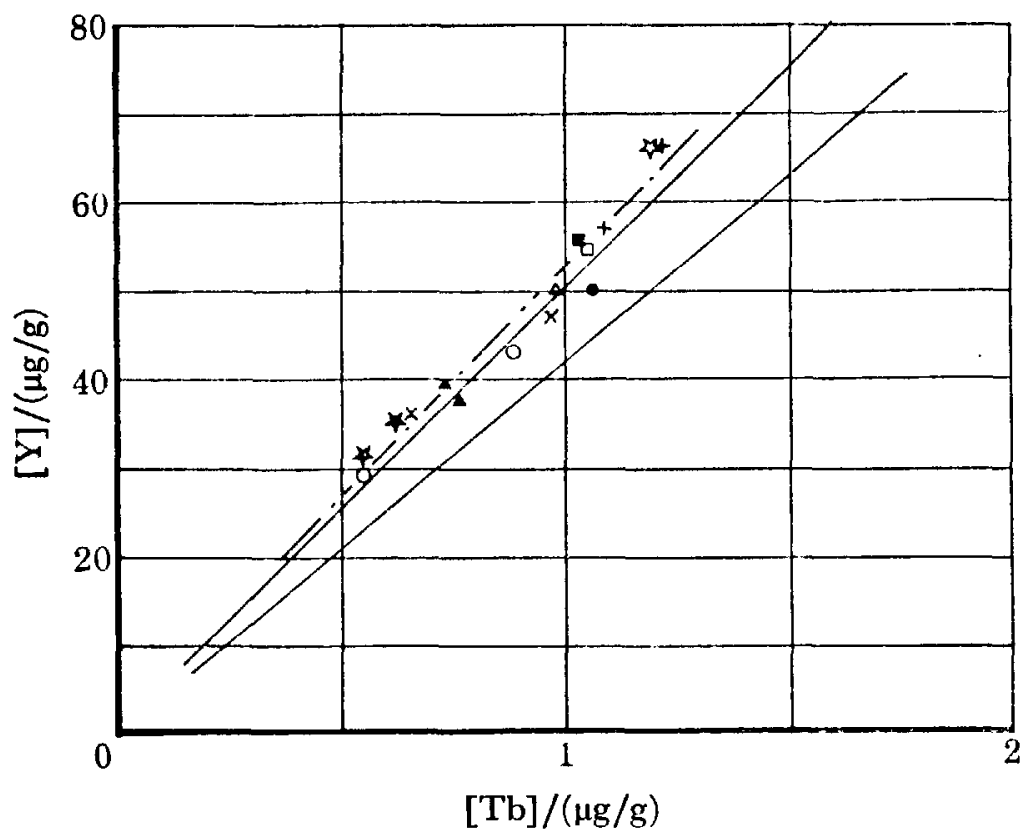

Figure 3. Y-Tb: the two continuous lines enclose the field of $\Lambda$ tlantic basalts (sce text for locations). The plotted points correspond to Pacific basalts recovered by Leg 54 (see text for locations). O, Hole 420; + , Hole 421 ; $\times$, Hole 422; $\triangle$, Hole 423; $\square$, Hole 424 and $424 \mathrm{~A} ; \mathrm{a}$, Hole $424 \mathrm{~B}$ and $424 \mathrm{C}$; $¥$, Hole 425; $\not$, Hole 427; $\triangle$, Hole 428 and $428 \mathrm{~A}$; O, Hole $429 \mathrm{~A}$.

\section{(a) $\mathrm{Y}-\mathrm{Tb}, \mathrm{Zr}-\mathrm{Hf}, \mathrm{Nb}-\mathrm{Ta}$ : chondritic primordial mantle}

We have been interested in studying the three first elements of the second and third transition series, $\mathrm{Y}, \mathrm{Zr}, \mathrm{Nb}$ and $\mathrm{Tb}, \mathrm{Hf}$, Ta respectively. It can be observed that in each group, group III Y-Tb (heavy rare earth), group IV $\mathrm{Zr}-\mathrm{Hf}$ and group $\mathrm{V} \mathrm{Nb-Ta,} \mathrm{both} \mathrm{elements} \mathrm{have} \mathrm{the}$ same ionic radii and the same charges. Correspondingly, by using the data obtained for different series of samples, it has been shown that both elements in each group have the same or very similar partition coefficients (Bougault et al. 1979). In addition, the three pairs can be classified as follows:

$$
D_{\mathrm{Y}} \approx D_{\mathrm{Tb}}>D_{\mathrm{Zr}} \approx D_{\mathrm{HP}}>D_{\mathrm{Nb}} \approx D_{\mathrm{T}^{\mathrm{a}}}
$$

$D_{\mathrm{z}}$ being the 'bulk partition coefficient' of element $Z$.

All of the samples from the different regions of the Atlantic ocean that have been studied fall in the ranges indicated in figure 3 for $\mathrm{Y}-\mathrm{Tb}$, in figure 4 for $\mathrm{Hf}-\mathrm{Zr}$ and in figure 5 for $\mathrm{Nb}-\mathrm{Ta}$ (Bougault et al. 1979). The samples recovered during Leg 54 in the Pacific ocean have been included in these figures. In figure 3, leg 54 samples plot in the upper part of the range defined by the Atlantic ocean; in figure 4, Leg 54 samples plot in the range of the Atlantic ocean, 
showing a similar dispersion. In figure 5, the Leg 54 samples are less numerous than in other figures owing to a contamination with $\mathrm{Ta}$ for some samples which unfortunately had been ground in a tungsten carbide mortar; the samples plotted, which were ground in an agate mortar, plot in the range of the Atlantic ocean (Joron et al. 1979). The open star represents the average point of the homogeneous unit of Hole 427 (Siqueiros Fracture zone, $8^{\circ} \mathrm{N}, 5 \mathrm{Ma}$ old); the triangle represents the average point of Holes $428 \mathrm{~A}$ and 428 (homogeneous unit) corresponding to the East Pacific Rise $\left(9^{\circ} \mathrm{N}, c a .2 \mathrm{Ma}\right.$ old $)$, open circles correspond to two single samples of Hole 429 A, East Pacific Rise ( $9^{\circ} \mathrm{N}$, ca. 4.5 Ma old).

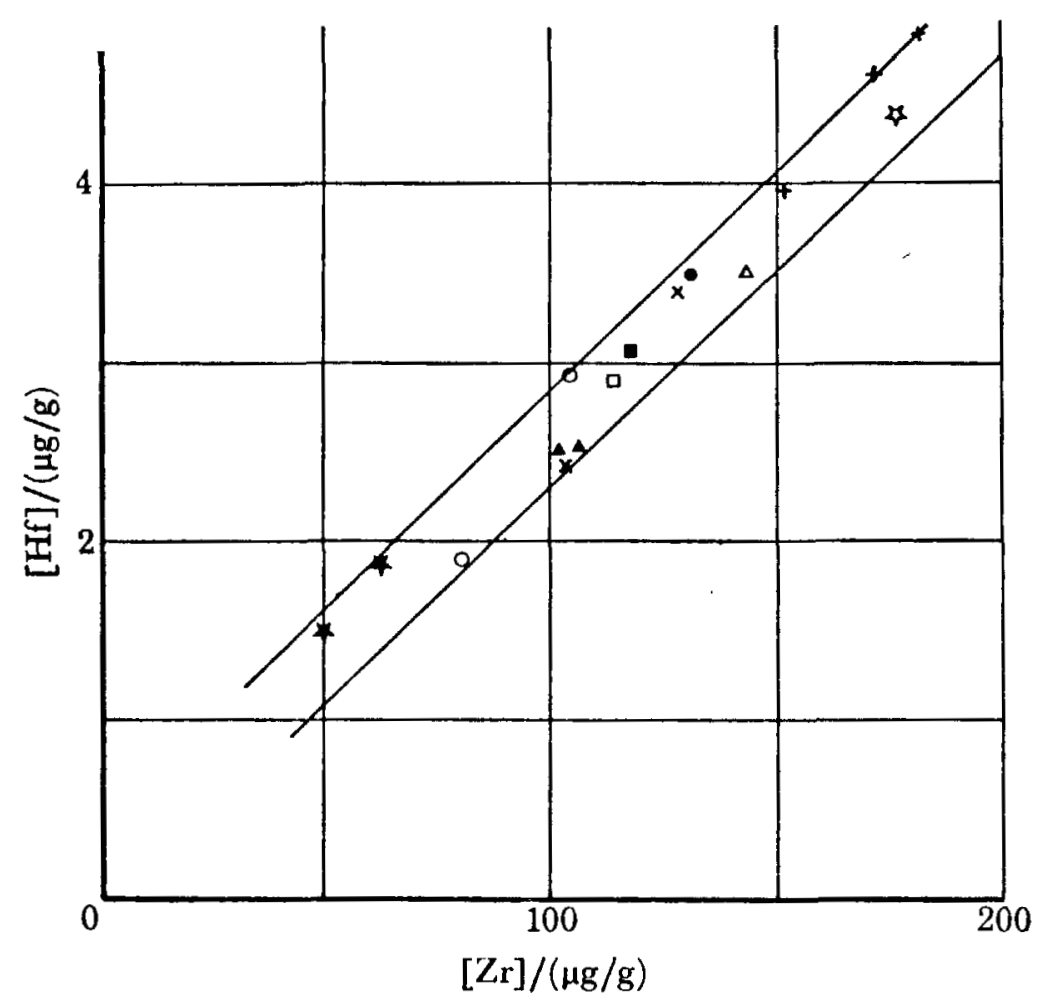

Figure 4. Hf- $\mathrm{Zr}$; same symbols as in figure 3.

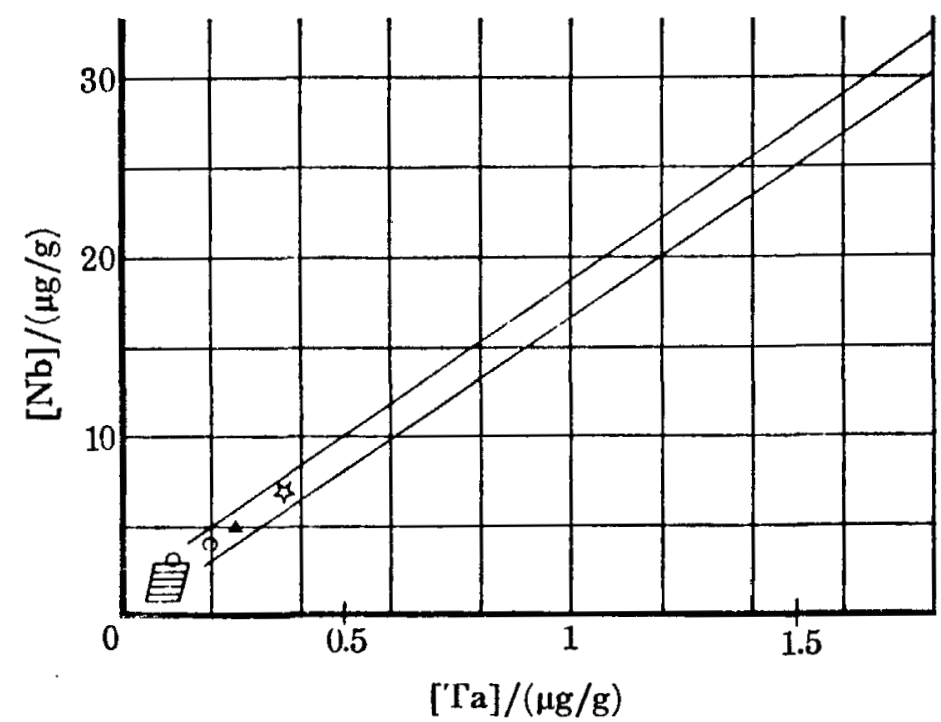

FIGURE 5. Nb-Ta; the two parallel lines enclose the field of Atlantic basalts; the small field near the origin includes Legs 51 and 52 samples (110 Ma old crust at $25^{\circ} \mathrm{N}$ in the Atlantic). The plotted points correspond to Leg 54 in the Pacific (see text). $¥$, Hole 427; $\triangle$, Hole 428 and $428 \mathrm{~A}$; O, Hole $429 \mathrm{~A}$. 
The fundamental result obtained is that the ratios $\mathrm{Y} / \mathrm{Tb}, \mathrm{Zr} / \mathrm{Hf}$ and Nf/Ta are constant or almost constant for a large variation of concentrations; in addition, we observe that the scatter of $\mathrm{Y} / \mathrm{Tb}$ is higher than the scatter of $\mathrm{Zr} / \mathrm{Hf}$ which in turn is higher than the scatter of $\mathrm{Nb} / \mathrm{Ta}$. This is closely related to the classification of partition coefficients of each pair and in agreement with the observation made earlier about the possibility of fractionation in connection with the value of partition coefficients. It can be deduced from these results that the mantle is homogeneous with respect to $\mathrm{Y} / \mathrm{Tb}, \mathrm{Zr} / \mathrm{Hf}$ and $\mathrm{Nb} / \mathrm{Ta}$ ratios. Table 3 shows a comparison of these ratios with the same ratios in chondrites; $\mathrm{Y} / \mathrm{Tb}$ is from Frey et al. (1968), $\mathrm{Zr} / \mathrm{Hf}$ from Ehman \& Rebagay (1970) and Nb/Ta from Graham \& Mason (1972). In lunar rocks, Wanke et al. (1975) found some variations for $\mathrm{Zr} / \mathrm{Hf}$ and $\mathrm{Nb} / \mathrm{Ta}$, but the values found are close to those of oceanic basalts. Taking into account the chondritic data, analytical precisions and comparisons of data from different laboratories the ratios $\mathrm{Y} / \mathrm{Tb}, \mathrm{Zr} / \mathrm{Hf}$ and $\mathrm{Nb} / \mathrm{Ta}$ which can be attributed to a primordial mantle (no variation of these ratios with magmatic processes and mantle history) favour a chondritic composition of the Earth.

\section{Table 3. Y/Tb, $\mathrm{Zr} / \mathrm{Hf}$ and $\mathrm{Nb} / \mathrm{Ta}$ Ratios IN OCEANIC Basalts and IN GHONDRITES}

$\begin{array}{lllc} & \mathrm{Y} / \mathrm{Tb} & \mathrm{Zr} / \mathrm{Hf} & \mathrm{Nb} / \mathrm{Ta} \\ \text { oceanic basalts } & \mathbf{4 2 \pm 5} & \mathbf{3 9} \pm 5 & \mathbf{1 6} \pm \mathbf{2} \\ \text { chondrites } & \mathbf{4 1 . 7} & \mathbf{3 0 - 4 0} & \mathbf{1 5 - 1 7}\end{array}$

\section{(b) $\mathrm{La} /(\mathrm{Nb}, \mathrm{Ta}) ; \mathrm{Th} / \mathrm{Ta}$ mantle heterogeneity}

It is well established that heavy and light rare earth elements fractionate. Bearing in mind our objective - to find possible large-scale heterogeneities in the mantle - it is necessary to choose a pair of elements that are not fractionated during basalt genesis. Thus La cannot be compared with $\mathrm{Tb}$. The bulk partition coefficient of La has been shown (Bougault et al. 1979) to be similar to the partition coefficient of $\mathrm{Nb}$ and $\mathrm{Ta}$. Hence, to investigate mantle heterogeneity, the relation La-Ta has been studied in all basaltic samples mentioned in $\S 2$. All of the samples in the Atlantic Ocean are plotted in figures 6 and 7. Samples at $36^{\circ} \mathrm{N}, 45^{\circ} \mathrm{N}$ and $63^{\circ} \mathrm{N}$ plot along a straight line (La against $\mathrm{Ta}$ ) whose slope is 9 . Samples at $22^{\circ} \mathrm{N}$ and $25^{\circ} \mathrm{N}$ (same 'flow line') plot along a line whose slope is 18 (figure 7).

At $36^{\circ} \mathrm{N}, 45^{\circ} \mathrm{N}$ and $63^{\circ} \mathrm{N}$ in the Atlantic, La does not show fractionation with respect to $\mathrm{Ta}$ even though the concentration of these elements varies by a factor of 50 (in figure 6 , the two points marked ' $\times 2$ ' correspond to concentrations twice those indicated on the figure). It can be deduced that the $\mathrm{La} / \mathrm{Ta}$ (or $\mathrm{La} / \mathrm{Nb}$ ) ratio is not affected by magma genesis; in consequence, the two ratios found ( 9 and 18) have to be attributed to mantle heterogeneity. This heterogeneity in the mantle is not random; it is a large-scale heterogeneity. It is clearly related to topographic highs, the ratio 9 being related to $36^{\circ} \mathrm{N}, 45^{\circ} \mathrm{N}$ and $63^{\circ} \mathrm{N}$ topographic highs and the ratio $18-22^{\circ} \mathrm{N}$ (deep rift valley). In this way, we find a similar variation to that shown by White \& Schilling (1978). In addition, this ratio has remained constant along flow lines: 9 for the three sites at $63^{\circ} \mathrm{N}$ perpendicular to Reykjanes Ridge; 9 for the Famous area and sites drilled perpendicular to the FAmous area during Leg $37 ; 18$ at $22^{\circ} \mathrm{N}$, two sites almost symmetric with respect to the ridge ( 7 and $10 \mathrm{Ma}$ old) and at $25^{\circ} \mathrm{N}$ (110 Ma old sites).

A plot of $\mathrm{Ta}-\mathrm{Th}$ is shown in figure 8. Th has the lowest partition coefficient among the investigated elements. Different ratios are observed for the different areas. In addition, in the Famous area for instance, different Hf/Ta ratios (elements which can fractionate because of 
their difference in partition coefficients) are observed; although the FAmous area is characterized by a constant $\mathrm{Ta} / \mathrm{Th}$ ratio.

According to the orders of magnitude of and the differences between partition coefficients of the hygromagmaphile elements we are able to demonstrate heterogeneity in the mantle on

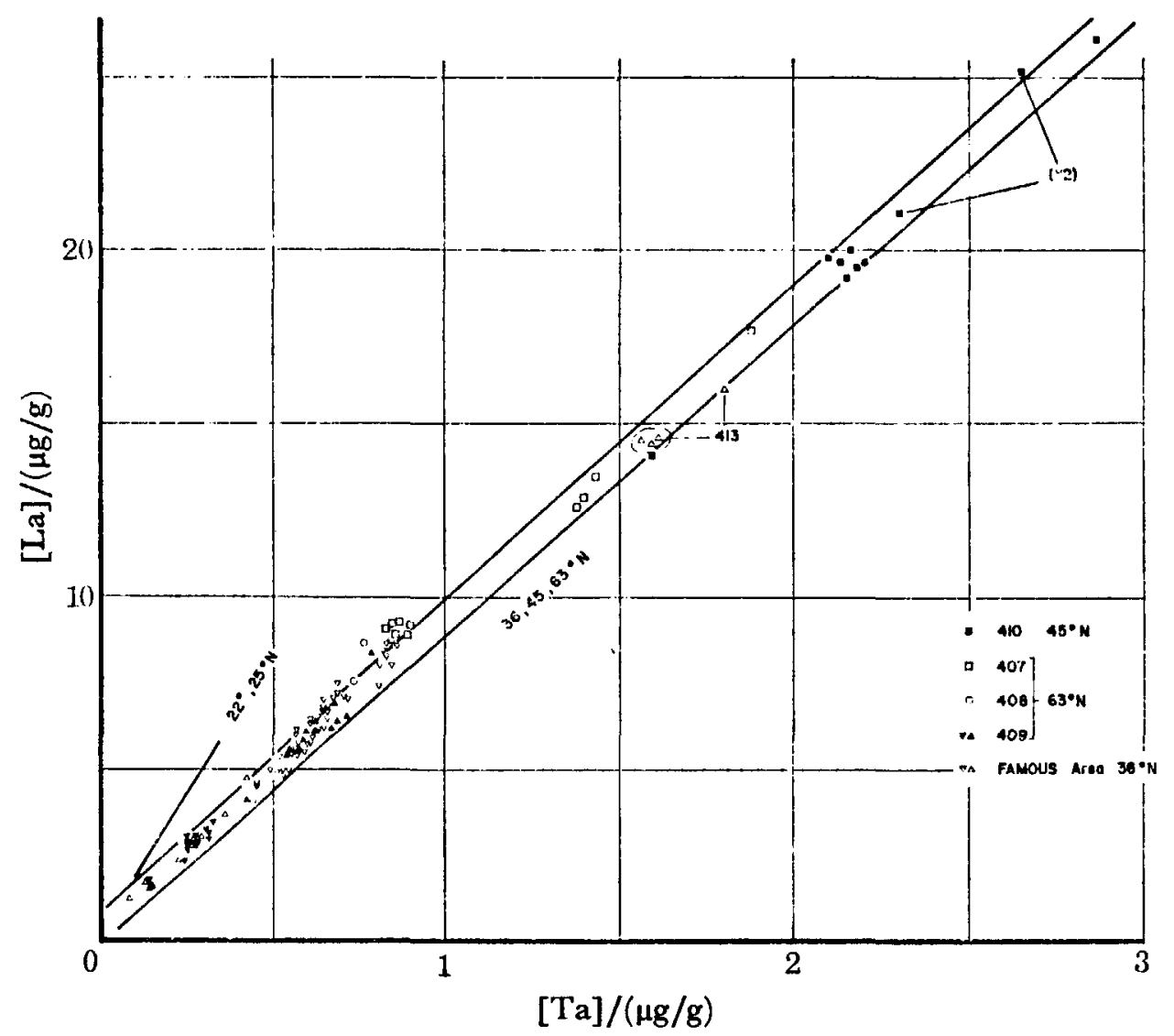

Figure 6. La-Ta plot for Atlantic basalts recovered between $36^{\circ} \mathrm{N}$ and $63^{\circ} \mathrm{N}$. Samples of Leg 37 at $36^{\circ} \mathrm{N}$ (up to $15 \mathrm{Ma}$ old) and samples recovered on the Mid-Atlantic Ridge at $36^{\circ} \mathrm{N}$ and at $63^{\circ} \mathrm{N}$ also plot within the parallel lines $(\mathrm{La} / \mathrm{Ta} \approx 9)$.

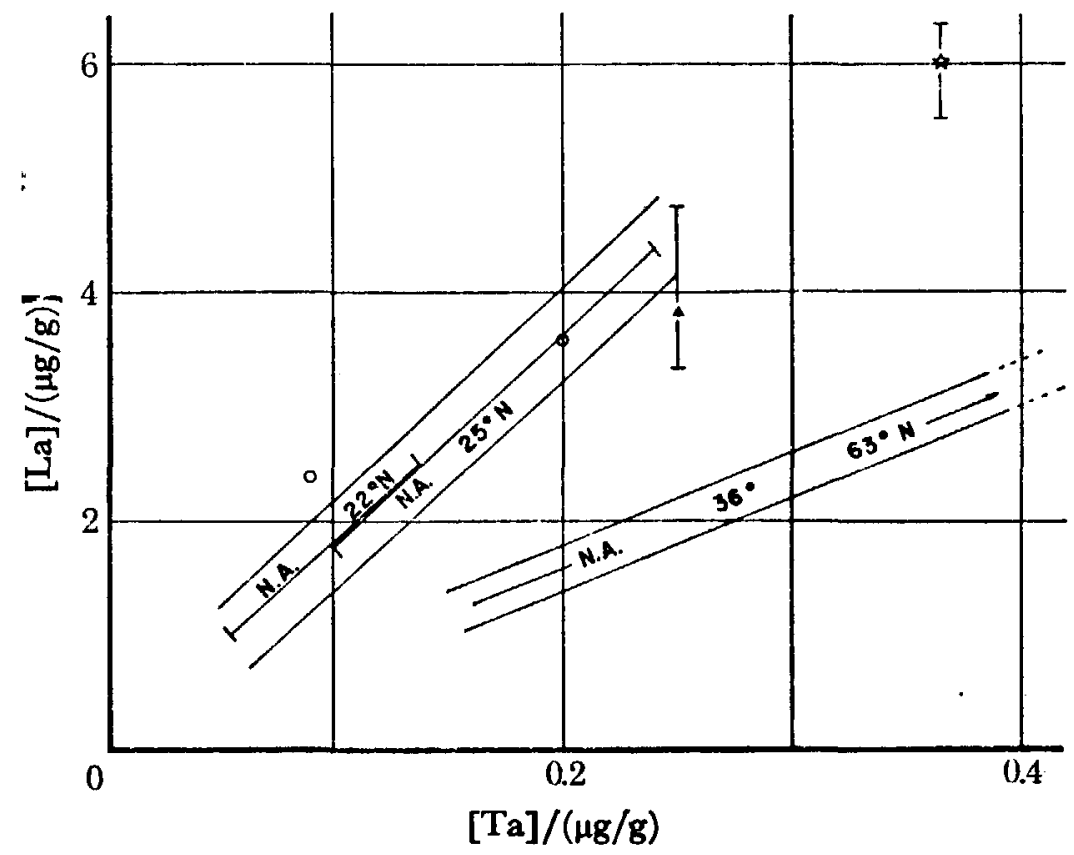

Figure 7. La-Ta plot showing fields for basalt samples recovered at $22^{\circ} \mathrm{N}$ (young crust) and $25^{\circ} \mathrm{N}$ (old crust) in the Atlantic and samples recovered by Leg 54 (points) in the Pacific ( $\mathrm{La} / \mathrm{Ta} \approx 18$ ). 
different scales: the $\mathrm{Nb} / \mathrm{Ta}$ ratio is unique and shows the primordial chondritic nature of the mantle; the $\mathrm{La} / \mathrm{Ta}$ ratio shows only two values related to topography; the $\mathrm{Ta} / \mathrm{Th}$ ratio shows different values for a single $\mathrm{La} / \mathrm{Ta}$ value. $\mathrm{Hf} / \mathrm{Ta}$ also shows different values (like heavy rare earth/light rare earth) for a single $\mathrm{Ta} / \mathrm{Th}$ value, within a single hole. We would not necessarily interpret this last observation ( $\mathrm{Hf} / \mathrm{Ta}$ variation) as mantle heterogeneity in the way that we have defined it. We consider that in this latter case there is an ambiguity between the nature of the mantle source and the process (partial melting) producing basalts which necessarily modifies the composition of the source.

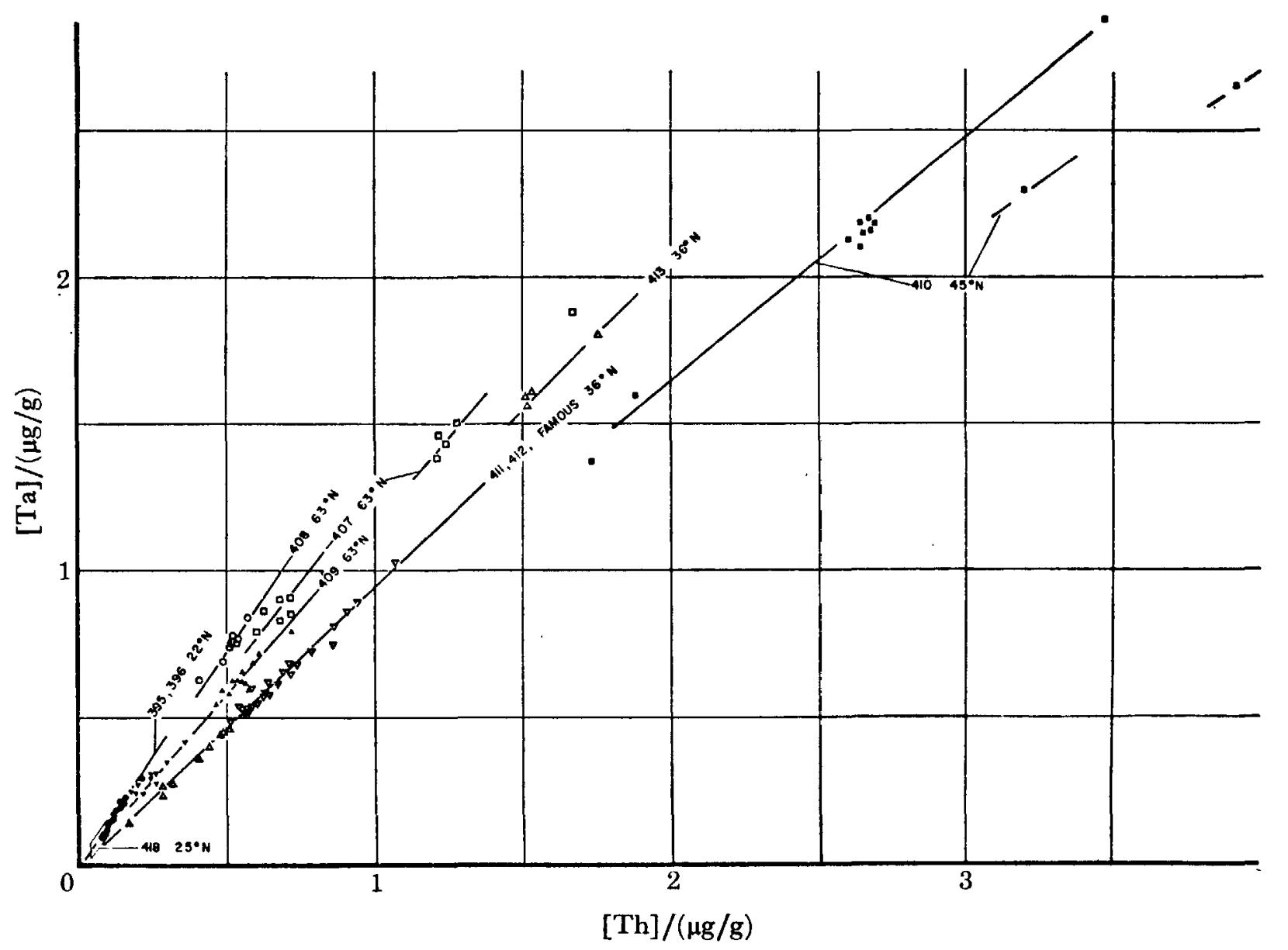

FigUre 8. Ta-Th relation for different series of samples recovered in the Atlantic ocean.

\section{Conclusions}

High partition coefficient elements $\mathrm{Co}, \mathrm{Ni}$ (and $\mathrm{Cr}$ to a lesser extent) do not show evidence of concentration variations in the mantle because of buffering by some minerals (e.g. olivine) during solid-liquid equilibrium.

According to the absolute and relative values of partition coefficients of hygromagmaphile elements, different features are observed in oceanic basalts:

(1) $\mathrm{Y} / \mathrm{Tb}, \mathrm{Zr} / \mathrm{Hf}$ and $\mathrm{Nb} / \mathrm{Ta}$ ratios are constant in all studied samples and are equal to these ratios in chondritic meteorites, which favours an initial chondritic composition for the 'primordial' mantle for these elements.

(2) Two values are observed for the $\mathrm{La} / \mathrm{Ta}$ ratio $(9$ and 18 ) and are closely related to the topography of the Mid-Atlantic Ridge; in addition the value 9 or 18 remains constant along 
a specific 'flow line' of the oceanic lithosphere. This may represent a very large-scale heterogeneity in the mantle which is related to latitude in the Atlantic ocean.

(3) For elements with increasing difference between their partition coefficients, $\mathrm{Ta} / \mathrm{Th}$ shows different values for a single $\mathrm{La} / \mathrm{Ta}$ ratio and then $\mathrm{Hf} / \mathrm{Ta}$ shows different values for a single $\mathrm{Ta} / \mathrm{Th}$ ratio. This demonstrates heterogeneities at smaller and smaller scales. We note that when the difference between partition coefficients is high (e.g. Hf-Ta) there is an ambiguity in that the ratio variations can be attributed to either local mantle heterogeneities or modern magmatic processes (e.g. partial melting).

We thank D. A. Wood and J. Tarney for comments, reading and correcting the manuscript.

\section{REFERENCES (Bougault et al.)}

Allègre, G. J., Javoy, M. \& Michard, G. 1968 In Origin and distribution of the elements (ed. L. H. Ahrens), pp. 913-928. Pergamon Press.

Arcyana, 1977 Deep Sea Res. 24, 566-589.

Aumento, F., Melson, W. et al. 1977 Initial reports of the Deep-Sea Drilling Project, vol. 37. (1008 pages.) Washington, D.G.: U.S. Government Printing Office.

Bougault, H. I 977 Bull. Soc. Géol. France, 19, 1207-1212.

Bougault, H. \& Allègre, C. J. 1979 In preparation.

Bougault, H. \& Hékinian, R. 1974 Earth planet. Sci. Lett. 24, 249-261.

Bougault, H., Joron, J. L. \& Treuil, M. 1979 In Implications of deep drilling results in the Atlantic Ocean (ed. M. Talwani), pp. 352-368. American Geophysical Union.

Boullier, A. M. \& Nicolas, A. I 973 In Lesotho kimberlites (ed. P. H. Nixon), pp. 57-66. Maseru: Lesotho National Development Corporation.

Burns, G. I 970 Mineralogical applications of crystal field theory. (224 pages.) Cambridge University Press.

Cox, K. G., Gurney, J. J. \& Harte, B. 1973 In Lesotho kimberlites (ed. P. H. Nixon), pp. 76-92. Lesotho National Development Corporation.

Curtis, C. 1964 Geochim. cosmochim. Acta 28, 389-403.

Dale, S. M. \& Henderson, P. 1972 In Rep. 24th Int. Geol. Congress, Montreal, vol. 10, pp. 105-111.

Dmitriev, L., Heirtzler, J. et al. 1978 Initial reports of the Deep-Sea Drilling Project, vol. 46. (436 pages.) Washington, D.C.: U.S. Government Printing Office.

Donnelly, W., Francheteau, J., Bryan, W., Robinson, P., Flower, M., Salisbury, M. et al. 1979 Initial reports of the Deep-Sea Drilling Project, vols 51, 52 and 53. Washington, D.C.: U.S. Government Printing Office. (In the press.)

Ehman, W. D. \& Rebagay, T. V. 1970 Geochim. cosmochim. Acta 34, 649-658.

Frey, F. A., Haskin, M. A., Poetz, J. A. \& Haskin, L. A. 1968 J. geophys. Res. 73, 6085-6098.

Graham, A. L. \& Mason, B. I 972 Geochim. cosmochim. Acta 36, 917-922.

Hakli, T. A. I968 Geochim. cosmochim. Acta 32, 449-460.

Hakli, T. A. \& Wright, J. L. I 967 Geochim. cosmochim. Acta 31, 877-884.

Hart, S. R., Davis, K. E., Kushiro, I. \& Watson, E. B. 1976 Bull. geol. Soc. Am. 8, 906.

Hékinian, R., Rosendahl, B. et al. 1980 Initial reports of the Deep-Sea Drilling Project, vol. 54. Washington, D.C.: U.S. Government Printing Office. (In the press.)

Joron, J.-L., Briqueu, L., Bougault, H. \& Treuil, M. 1979 In Hékinian et al. (1980).

Langmuir, G. H., Bender, J. F., Bence, A. E., Hanson, G. N. \& Taylor, S. R. 1977 Earth planet. Sci. Lett. 36, $133-156$.

Luyendyk, B. P., Cann, J. R. et al. 1979 Initial reports of the Deep-Sea Drilling Project, vol, 49. (976 pages.) Washington, D.C.: U.S. Government Printing Office.

Melson, W., Rabinowitz, P. et al. 1978 Initial reports of the Deep-Sea Drilling Project, vol. 45. (717 pages.) Washington, D.C.: U.S. Government Printing Office.

Nixon, D. H. \& Boyd, F. R. 1973 In Lesotho kimberlites (ed. P. H. Nixon), pp. 48-56. Maseru: Lesotho National Development Corporation.

Sato, H. 1977 Lithos 10, 113-120.

Treuil, M. 1973 Thèse, Université d'Orléans.

Treuil, M. \& Joron, J. L. I975 Soc. ital. Mineral. Petrol. Milano 31, 125-174.

Wanke, H., Palme, H., Baddenhausen, H., Drelbas, G., Jagoute, E., Kruse, H., Palme, C., Spettel, B., Teschke, F. \& Thacker, R. 1975 Proc. 6th Lunar Sci. Conf., pp. 1313-1340.

White, W. \& Schilling, J. G. 1978 Geochim. cosmochim. Acta 42, 1501-1516. 